\section{Research centre gets fixed home}

\section{Washington}

$\mathrm{ON}_{\mathrm{N}}$ an unseasonably cold, blustery day last month in the Washington suburb of Rockville, the proud parents of the Center for Advanced Research in Biotechnology (CARB) held a ceremonial groundbreaking of what will some day be CARB's new home. A joint venture of the National Bureau of Standards, the University of Maryland and the local county govern-

Information technology

\section{New institute}

FINAL preparations are being made for the opening of Britain's first higher education institute devoted to the research and teaching of information technology (IT), the marriage of telecommunication and computer disciplines, supported entirely by industry and by its users.

The new institute, to be based in Milton Keynes in Buckinghamshire just north of London, has been possible through an initial tranche of $£ 3.5$ million from more than 25 companies in the IT field, in an attempt to reduce the growing shortage of IT skills in the United Kingdom.

The institute has been created in partnership with the Cranfield Institute of Technology in Bedfordshire, whose vicechancellor, Sir Henry Chilver, has been the chief driving force behind the project.

The institute is a new dimension in British higher education and one that has provoked detectable hostility from some in established academic institutions who suspect that industrially-funded education, the preference of the Prime Minister Mrs Margaret Thatcher, will undermine the already shaky finances of the British educational establishment.

Supporters of the institute, however, consider that its curriculum will be more appropriate to the needs of an industry already desperately short of key skills, and that its existence will lighten the burden now falling on traditional education institutions, which have been unable to satisfy the appetite of industry.

The future of the institute will depend on whether it proves to be commercially viable, which is reflected in the management structure. A managing director, Dr Allan J. Fox, reporting to a board, replaces the conventional hierarchy of vicechancellor and senate. Fox was previously deputy director (applied physics) at the Royal Signals and Radar Establishment at Malvern.

Initial areas of research are to include software engineering, parallel processing, artificial intelligence in computers and the communications of computers linked through networks. ment. CARB will focus initially on protein engineering and rational drug design.

For now, CARB is housed in temporary quarters in Gaithersburg, Maryland, on the campus of the Bureau of Standards. CARB director Kevin Ulmer says the centre will take advantage of the bureau's expertise in fine measurement technologies, essential to making detailed protein structural determinations. The bureau also possesses a CYBER 205 supercomputer needed to make calculations for modelling of atomic interactions in protein molecules. Ulmer says that CARB will provide the bureau with a window into biotechnology, an area in which it has not traditionally had a very large presence.

For the University of Maryland, CARB is only one aspect of a major thrust in the realm of biotechnology. The Maryland Biotechnology Institute includes centres devoted to marine biotechnology, agricultural, medical and ethical aspects of biotechnology in addition to CARB. The university's 1987 budget allots $\$ 5.6$ million to these institutes, including provision for 75 full-time positions. Rita Colwell, university vice president for academic affairs, says Maryland is a logical place to house these centres, because the 50 -mile corridor between Washington and Baltimore is rich in biotechnology companies and government research laboratories.

Montgomery County, where CARB is located, is also trying to take advantage of the population characteristics of the Baltimore-Washington corridor. The county has created the Shady Grove Life Sciences Center, and is providing funds and space to both the University of Maryland (50 acres) and John Hopkins University ( 35 acres) for new campuses, has begun work on what will be a teaching facility for high-technology graduate programmes, and the University of Maryland has begun CARB. County officials say the idea is to compete with the San Francisco Bay area and the Boston area for biotechnology companies. Montgomery County is home for the National Institutes of Health, the National Bureau of Standards and the Food and Drug Administration. Some four dozen biotechnology companies have already located in the county.

CARB's major initial thrust - protein structure - has in just the past two years been an area of intense interest. Thomas Steitz of Yale University calls the resurgance of structural biology "spectacular". Steitz attributes the renewed interest to strides in molecular biology that have provided large quantities of molecules of interest for study. Ability to perform sitedirected mutagenesis has spurred efforts to derive a theoretical understanding of how DNA sequence changes would affect the structure of the resulting protein.

But the increased interest in structural biology means that CARB will face stiff competition for personnel and funds. CARB has offered positions to seven scientists to form its senior staff, but so far only one has accepted. Ulmer admits it is hard to persuade industry to enter collaborative projects without a full staff on board. The National Bureau of Standards and the University of Maryland will together provide CARB with about \$3 million annually, but Ulmer hopes to increase that figure several-fold through contracts and grants from both government and industry.

Raymond Salemme, who directs Du Pont's efforts in protein structure, says

\section{Alaskan environment}

\section{Long row ahead}

Washington

THE first salvo in what is likely to be the major energy debate of 1987 was fired last week when the Department of the Interior recommended leasing 1.5 million acres of the Arctic National Wildlife Refuge in Alaska for oil and gas exploration. The government believes the land lying along the northern Alaska coast could be "the most outstanding oil and gas frontier in North America". But environmental groups call the same land a unique treasure house of wildlife, and doubt whether the area can be developed without severe ecological disruption.

Since 1980, when Congress set aside 17.9 million acres of Alaskan land for a wildlife refuge, the government has been struggling over what to do about its coastal plain. Environmental groups wanted the land declared a national wilderness, putting it off limits for oil and gas exploration. But the Interior Department's report proposes a full leasing plan, arguing that industry can conduct its operation in a way that will minimize environmental damage.

The report argues that the national need for oil and gas makes development of the coastal plain essential. A 150-mile pipeline would carry oil from the eastern boundary of the coastal plain to the head of the trans-Alaska pipeline at Prudhoe Bay.

Alaskan politicians are enthusiastic about the Interior Department's plans. The Alaskan economy is in the doldrums. The government's report maintains that oil exploration in the coastal plain will reduce US dependence on foreign oil, enhance national security and bring a more favourable balance of trade.

The coastal plain is inhabited by a wide variety of fauna, including bears, polar bears, musk oxen, foxes, sheep and migratory birds. But development will have the greatest impact on the Porcupine herd of some 180,000 migratory caribou. Appro- 